\title{
A SWOT ANALYSIS OF DEVELOPMENT IN NORTH EAST INDIA
}

\section{Ranju Kumar Bharali}

\author{
Assistant Professor Dept. of Economics, Cinnamara College.
}

ABSTRACT North East India comprising eight North Indian States covering 8 percent of India's land surface and 3.1 percent of India's population is a centre stage of India's Act East Policy as this region is a gateway to South East Asia. This region has great potential to develop not just as a self sustaining economic unit but also critical for overall development of the country. North East India has vast natural resources. The region is endowed with rich hydro power potential, coal, petroleum, natural gas and other minerals, forest wealth, horticulture etc. As about 98 percent of the region is covered with international border it has great potential for trade and collaboration. Again the region has vast potential for all types of tourism. Inspite of all these, the region is relatively backward. This might be due to lack of proper developmental strategy and policy. To formulate proper roadmap and strategy for development it is very necessary to analyse the strength, weakness, opportunities, and threat (SWOT) of North East India. This paper makes an attempt for SWOT analysis of development in North East India which may be helpful in making proper policy initiatives and strategy for overall development of the region.

KEYWORDS : Development, SWOT, North East India.

\section{INTRODUCTION:}

North Eastern Region has got its definite identity due to its peculiar physical, economic and socio-cultural characteristics. This region is a treasure house of various resources and at the same time is a store house of diverse problem. (P.K. Dhar, 2013). The North Eastern Region of India is composed of eight states, covering $263,179 \mathrm{sq} \mathrm{km}$ which is about 8 percent of the total geographical area of the country (N.B. Singh, 2006). It is a land locked region and about 4500 $\mathrm{km}$ i.e. 98 percent of its border is with five countries viz, Bangladesh, Myanmar, Bhutan, Nepal and China. The North Eastern region has great potential to develop not just as a self sustaining economic unit of India but also contribute to the success story of the country. This region is endowed with huge untapped natural resources and is acknowledged as the eastern gateway for the country's "Act East Policy".

The total population of the region is about 38 million, 3.8 percent of country's population of which Assam contributes 68 percent of the total population. Assam recorded the highest density of population with 398 per sq. km and Arunachal Pradesh lowest density of population with 17 per sq. km. Again Mizoram records the highest literacy rate with 91.33 percent which is higher than the national average and Arunachal Pradesh records the lowest literacy rate with 54.3 percent (Statistical abstract).

The region is richly endowed with bio-diversity, hydro potential, minerals like oil and natural gas, coal, limestone etc and forest wealth. Over 10 percent of the forest product requirements in the country are met from this region. The region has very high potential to generate hydropower, i.e. about 80 percent of the total hydropower potential in this country. With varied geo-climatic condition the region is very suitable for horticulture, floriculture and other plantation crops. A variety of fruits like pineapples, banana, orange, lemon, mango, papaya are abundantly grown in this region. The region is famous for most variety of orchids in the country. Tea is major plantation crop grown in the region and is largest producer in the country. The region is also richly endowed with variety of medicinal plant. However due to lack of proper infrastructure, transport and communication system, finance and geo political conditions of the region these resources largely remain untapped.

\section{OBJECTIVES AND METHOD:}

To harness the full potential of this region significant investment and development initiatives will be required in upgrading the region's infrastructure (Physical and financial), education and skill development. All these have to be done keeping in mind the need for preserving the rich bio-diversity and diverse ethnic culture of the region. To formulate realistic plan and policies for all round development of the region keeping in mind the resource potential of the region it is very essential to analyze the Strength, Weakness/Opportunities and Threat (SWOT) of development in this region. Such on attempt is made in this paper. The study is purely analytical in nature. All information was taken from secondary sources such as books, journals and the material available in the Internet.

\section{SWOT Analysis of the North Eastern Region of India}

Strength:

1. Abundance of forest and mineral resources are great strength for development of the region. North Eastern Region is very much rich in respect forest resources. About 64.2 percent of the total geographical area of this region is covered by forest. Such a huge forest resource is a base for forest base economy of the region. This region is also rich in mineral resources like crude petroleum, natural gas, limestone, dolomite, uranium, fire clay, kaoline etc.

2. Rich water resource is another strength of North Eastern Region. Due to favourable impact of monsoon the entire North Eastern region is experiencing adequate quantity of rainfall. The Brahmaputra and Barak are two major rivers which have 35 and 9 tributaries respectively, each of which has considerable catchment area. The rivers of North Eastern Region are the store house of Hydro power potential.

3. Presence of numerous tea estates are a strength for the economy of this region. The geographical conditions of this region are very suitable for tea plantations. Tea industry is an important source of capital formations of this region.

4. Presence of diverse ethnic tribal culture each with unique customs and traditions.

5. Rich bamboo reserves of this region is a great strength for the region to develop bamboo based economy and handicrafts.

6. Natural tourism sites like Loktak lake of Manipur, Majuli (The largest river island), National Parks and sanctuaries like Kaziranga, Manas etc are the strength for this region.

7. Relatively clean and pollution free environment.

\section{Weaknesses:}

1. Lack of sound transportation and communication system is a foremost weakness for development of this region. Geographical isolation, difficult terrain and lack of proper 
attention are some of the factors behind this problem. The development of railway and road transport facilities in this region is very minimum considering its need. Excluding, Assam the other North Eastern States are having either no rail line or very insignificant rail line with rest of the country.

2. Proneness to natural calamities is another weakness of this region. North eastern states are among those few states which are every now and then visited by natural calamities such as flood, landslide, erosion etc. Every year flood and landslide caused huge damage to crops, cattle, houses, roads and public properties in various NE states.

3. Limited tourism infrastructure facilities is another weakness. Fewer accommodation facilities, which are insufficient to cope up with the demand and are of poor qualities.

4. An important weakness for North Eastern Region is that this region is landlocked. The region has no direct accessibility to sea which is a great hurdle for development of trade in this region.

Opportunities:

1. Tourism is one sector where the region has comparative advantage. With bountiful nature's breath taking scenic beauty, salubrious climatic conditions, extraordinary diverse rich art and cultural heritage of the people this region can become hotspot of eco tourism, rural tourism and adventure tourism. Tourism involves a vast network of business activities including hotels, restaurants, transport agencies and several other related activities. Hence, tourism can generate more employment in this region than any other activities.

2. As nearly 98 percent of the border of NE region is covered by foreign countries, this region has great opportunity for development of border trade. Development of border trade would not only provide an opportunity to revive the local manufactured units but also serve as transit corridor for the mainland big industrial units to explore vast Asian market. This would also bring centrality and visibility of the otherwise peripheral North Eastern Region (Verghese, BG). It is with this vision the look east policy/Act East Policy was initiated.

3. There is great opportunity for development of handloom and handicraft industries. Handloom and weaving is a traditional skill acquired by the local community. Based on cane and bamboo reserves there is opportunity for development of cane and bamboo craft cottage industries which can be alternative source of employment and attraction for tourism.

Threats:

1. Overuse and commercialization of eco-sensitive zone could lead to depletion of resources and weakening of attraction.

2. Disturbed law and order condition and growing insurgencies.

3. Land banks and land availability if not addressed will limit private sector investment.

4. Increasing migration of rural people to urban areas for employment prospects is also a threat.

\section{CONCLUSION:}

The SWOT analysis of NER shows the picture that the strong natural resource base like forest resource, mineral resource and water resource are the greatest strength of North Eastern states which can be property utilized to overcome the weakness, then only we can grab the opportunities of development. The region is landlock. But this weakness can be converted to opportunities by developing border trade as 98 percent of the border of this region is international boundary. Again the presence of hills, river, lakes, forest etc. makes this region natural hot spot for tourism. This SWOT analysis will naturally help in formulating proper policy initiatives to utilize the strength, address the weaknesses, grab the opportunities and overcome the threat for the development of North Eastern Region.

\section{REFERENCES:}

1. Dhar, P.K.(2013) The Economy of Assam including Economy of North-East India, Kalyani Publisher

2. Verghese, B.G. Unfinished Business in the Nort- East: Pointers Towards Restructuring, reform, Reconciliation and Resurgence, Seventh Kamal Kumari Memorial Lecture.

3. Singh. N.B Globalization and Nort-East India: Challenges and Opportunities-NIT Silchar, www.nits.ac.in

4. Emerging North-East India: Economically and Socially Inclusive Development Strategies, KPMG, FICCI

5. India's North-East: Diversifying Growth Opportunities, www.pwc.com/in

6. North-Eastern Region Vision 2020, Ministry of Development of North-Eastern region, North-East Council 